\title{
Provincial Disparities of Growth Hormone Coverage for Young Adult Survivors of Paediatric Brain Tumours across Canada
}

\author{
Disparités provinciales dans la couverture pour \\ l'hormone de croissance chez les jeunes adultes ayant \\ survécu à une tumeur cérébrale infantile au Canada
}

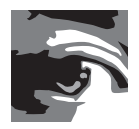

HAROON HASAN, BSC, MPH

Project Manager, Department of Radiation Oncology,

BC Cancer Agency, Vancouver, BC

FUCHSIA HOWARD, RN, PHD

Post-Doctoral Fellow, School of Population \& Public Health,

Faculty of Medicine, University of British Columbia, Vancouver, BC

STEVEN G. MORGAN, PHD

Professor E Associate Director, Centre of Health Services and Policy Research,

University of British Columbia, Vancouver, BC

DANIEL L. METZGER, MD

Paediatric Endocrinologist E Clinical Professor, University of British Columbia,

Clinical Investigator, Child Family Research Institute,

Endocrinology E Diabetes Unit, BC Children's Hospital, Vancouver, BC

ANDREA C. LO, MD

Radiation Oncology Resident, Department of Radiation Oncology, BC Cancer Agency,

Vancouver, BC

KAREN GODDARD, MBCHB

Radiation Oncologist, Department of Radiation Oncology, BC Cancer Agency,

Clinical Associate Professor, University of British Columbia, Vancouver, BC

On behalf of the authors (see Acknowledgements) 


\title{
Provincial Disparities of Growth Hormone Coverage for Young Adult Survivors of Paediatric Brain Tumours across Canada
}

\begin{abstract}
Background: Young adult survivors of paediatric brain tumours (PBTs) who have been treated with radiation therapy will likely be severely growth hormone-deficient when retested at the achievement of final height. Growth hormone replacement therapy (GHRT) is administered to treat growth hormone deficiency (GHD). Public drug coverage for GHRT falls under the responsibility of provincial governments across Canada. This study sought to determine the extent of public drug coverage and cost in each Canadian province for GHRT to treat GHD during adulthood for young adult survivors of PBTs.

Methods: Data were collected from provincial government resources and drug formularies from 2012-2013 on the extent of coverage for GHRT based on a clinical case scenario representative of a young adult survivor of a PBT with childhood-onset radiation-induced GHD, the ingredient cost for GHRT and the applicable provincial public drug plan cost-sharing policies. A model was then created to simulate out-of-pocket costs incurred by a young adult male and a young adult female survivor of a PBT for one year of GHRT in each province with applicable cost-sharing arrangements and levels of low annual individual total income that best represent the majority of young adult survivors of PBTs. Out-of-pocket costs were expressed as a percentage of annual income. Comparisons were made between provinces descriptively, and variation among provinces was summarized statistically.

Results: Alberta, Manitoba, Ontario, Quebec, New Brunswick, and Newfoundland and Labrador provide coverage for GHD during adulthood on a case-by-case basis, while British Columbia, Saskatchewan, Nova Scotia and Prince Edward Island provide no coverage. The percentage of annual income to fund GHRT across the provinces without public coverage ranged from $14.4 \%$ to $25.5 \%$ for males and $21.5 \%$ to $38.3 \%$ for females, and with public coverage was $0.0 \%$ to $4.1 \%$ for males and $0.0 \%$ to $5.0 \%$ for females.

Interpretation: There are considerable out-of-pocket costs and variation in coverage provided by provincial public drug plans to fund GHRT for young adult survivors of PBTs with GHD. The implementation of a national drug formulary could potentially prevent undue financial hardship and remove disparities resulting from variations in provincial drug plans.
\end{abstract}

\section{Résumé}

Contexte: Les jeunes adultes ayant survécu à une tumeur cérébrale infantile (TCI) après un traitement par radiothérapie demeurent très susceptibles de manifester une déficience en hormone de croissance lors d'un examen effectué à la fin de la croissance. L'hormonothérapie de remplacement (HTR) est employée pour traiter la déficience en hormone de croissance (DHC). Au Canada, la couverture publique de l'HTR est du ressort des gouvernements provinciaux. Cette étude visait à déterminer, pour chacune des provinces canadiennes, l'étendue et les coûts pour la couverture de l'HTR comme traitement de la DHC chez les jeunes adultes qui ont survécu à une TCI.

Méthodes : Les données - recueillies entre 2012 et 2013 à l'aide des listes de médicaments et auprès de sources gouvernementales provinciales - portaient sur l'étendue de la couverture 
pour l'HTR en fonction d'un scénario de cas clinique représentatif d'un jeune adulte ayant survécu à une TCI et présentant une DHC attribuable à la radiothérapie. Les données portaient également sur le coût des ingrédients pour l'HTR et sur les politiques de partage des coûts dans le cadre du régime provincial d'assurance médicaments. Un modèle a été conçu afin de simuler les coûts déboursés par un jeune homme et une jeune femme adultes ayant survécu à une TCI, et ce, pour une année de traitement par HTR dans chacune des provinces, en tenant compte des ententes de partage des coûts et des niveaux minimums de revenu annuel représentatifs de la majorité desdits jeunes adultes. Les coûts déboursés étaient exprimés en pourcentage du revenu annuel. Des comparaisons descriptives ont été effectuées entre les provinces. L'écart entre les provinces a été calculé statistiquement.

Résultats : L’Alberta, le Manitoba, l'Ontario, le Québec, le Nouveau-Brunswick ainsi que Terre-Neuve-et-Labrador offrent une couverture pour traiter la DHC chez les adultes, au cas par cas. La Colombie-Britannique, la Saskatchewan, la Nouvelle-Écosse et l'île-du-PrinceÉdouard noffrent pas une telle couverture. Le pourcentage du revenu annuel pour financer l'HTR dans les provinces sans couverture varie de 14,4 à 25,5\% pour les hommes et de 21,5 à $38,3 \%$ pour les femmes. Dans les provinces qui offrent la couverture, ce pourcentage varie de 0,0 à 4,1\% pour les hommes et de 0,0 à $5,0 \%$ pour les femmes.

Interprétation: Les coûts à débourser et l'écart de la couverture offerte dans le cadre des régimes provinciaux d'assurance médicaments varient considérablement pour ce qui est du financement de l'HTR pour les jeunes adultes ayant survécu à une TCI et présentant une DHC. La mise en place d'une liste nationale de médicaments pourrait éventuellement aider à prévenir un fardeau financier excessif et à éliminer les disparités qui découlent de l'écart entre les régimes provinciaux d'assurance médicaments.

PProximately 850 CHILDREn (o-I4 Years) are Diagnosed With CANCER
every year in Canada, and 20\% of these diagnoses account for cancers of the central
nervous system (Canadian Cancer Society 2008). The five-year survival rate for children diagnosed with a brain tumour is over $70 \%$, and the majority will become long-term survivors because of improvements in diagnostic procedures and treatment (Canadian Cancer Society 2008; Ries et al. 2004). Although cured of the cancer, survivors of a paediatric brain tumour (PBT) are at significant risk of developing medical, neurocognitive and psycho-social health complications as a result of their therapy and underlying disease (Turner et al. 2009).

Growth hormone deficiency (GHD) is a frequent complication observed after radiation therapy for the treatment of a PBT (Chemaitilly and Sklar 2010). Approximately 80\% of individuals treated with higher doses (>30 Gray units [Gy]) of radiation therapy develop GHD within five years of treatment (Chemaitilly and Sklar 2010; Sklar and Constine 1995). GHD is associated with negative metabolic and physiological consequences, increased cardiovascular risk and reduced quality of life (Alexopoulou et al. 2010). The majority of survivors 
of PBTs treated with radiation therapy will be severely growth hormone-deficient when retested at the completion of final height and would benefit from growth hormone replacement therapy (GHRT) (Darzy and Shalet 2006; Gleeson et al. 2004; Stanhope 2004).

The goal of GHRT is not isolated to optimizing achievement of final height. Young adult patients with childhood-onset GHD whose GHRT is discontinued after reaching final height exhibit negative metabolic and physiological disease outcomes, which include reduced lean mass and muscle strength as well as an abnormal lipid profile and body composition (Ho 2007; Hulthén et al. 2001; Koranyi et al. 2001). Studies have shown that these manifestations of GHD are reversible through GHRT, and therapy has been attributed to improvements in body composition, metabolic and cardiovascular parameters, muscle strength, bone-mineral density and quality of life (Alexopoulou et al. 2010; Carroll et al. 1998).

Growth hormone secretion will slow down over time in patients with radiation-induced GHD (Gleeson et al. 2004; Toogood et al. 1995). Therefore, PBT survivors diagnosed with radiation-induced childhood-onset GHD are likely to develop severe GHD during adulthood (Gleeson et al. 2004). Endocrinology consensus guidelines recommend that GHRT should not be discontinued in young adults with persistent GHD after reaching final height, in order to achieve full somatic development (Ho 2007).

Although studies have validated numerous benefits attributed to GHRT, it should be noted that such therapy has potential risks. Side effects have been observed in $5 \%$ to $20 \%$ of patients shortly after the initiation of GHRT (Alexopoulou et al. 2010; Molitch et al. 2006; Nilsson et al. 2007). The recommendation of GHRT to treat GHD in adults is justified in patients who test severely growth hormone-deficient after the achievement of final height, which comprises the majority of young adult survivors of PBTs treated with radiation therapy (Alexopoulou et al. 2010; Darzy and Shalet 2006; Gleeson et al. 2004; Stanhope 2004).

There is no national standard for coverage of outpatient medications in Canada, including GHRT, because outpatient medications are not covered under the Canada Health Act (Madore 2005). The Canada Health Act requires provincial governments to provide universal coverage for medically necessary hospital and physician services but not outpatient medications, a situation that has led to provincial governments developing independent public drug plans that often reflect population demographics and provincial political, fiscal, legal and ethical views (Daw and Morgan 2012; Madore 2005; Rabinovitch 2004; Ungar and Witkos 2005). This situation has led to documented variations in the drugs that are covered under provincial programs, the patients who are covered and the levels of public subsidy. Such variations in coverage policy cause disparities in out-of-pocket costs and health outcomes for patients requiring essential medications (Coombes et al. 2004; Daw and Morgan 2012; Demers et al. 2008; Law et al. 2012; Ungar and Witkos 2005). Provincial governments determine their own terms and conditions regarding coverage of outpatient medications, including coverage of expensive therapies to treat rare childhood disorders or diseases such as childhood-onset radiation-induced GHD (Ungar and Witkos 2005). This variance creates opportunities for inequitable access to medications and undue financial hardship. 
GHRT is expensive and unaffordable for many without the assistance of public drug coverage. The cost, on average, of one year of GHRT to treat GHD during adulthood was estimated in adults to be $£ 3,424$ (CAD\$5,574) (Bryant et al. 2002). It is estimated that each year 42 young adult survivors of PBTs in Canada will be growth hormone-deficient upon retesting after the achievement of final height and would benefit from GHRT (Appendix A). Consequently, public drug coverage of GHRT to treat GHD during adulthood would have a noticeable economic impact on the Canadian healthcare system. However, the cost of untreated GHD has a higher economic burden on society owing to lost production and high medical consumption in comparison to the average population (Ehrnborg et al. 2000; Hakkaart-van Roijen et al. 1998; Hernberg-Ståhl et al. 2001; Jonsson and Nilsson 2000; Sanmarti et al. 1999). Studies have shown there is a decrease in healthcare consumption in adults receiving GHRT who previously had untreated GHD, a finding that can be attributed in part to the increase in quality of life resulting from GHRT (Hernberg-Ståhl et al. 2001; Saller et al. 2006; Svensson et al. 2004).

Although public coverage is granted for GHRT during childhood in Canada, the extent of public coverage across the provinces is unknown for survivors of PBTs who continue to present with GHD into adulthood and require GHRT (Ungar and Witkos 2005). Furthermore, there are currently no studies in Canada that assess the financial burden young adult survivors of PBTs with GHD incur to obtain GHRT. Survivors are at significant risk for multiple long-term health problems (late effects), many of which are preventable or manageable through early intervention, and inevitably will result in increased healthcare consumption if left unaddressed (Landier et al. 2004; Turner et al. 2009). Additionally, survivors of PBTs have a considerable impact on healthcare resources, and thus it is crucial to understand the extent of the associated costs within this population in order to help alleviate the burden on the Canadian healthcare system. The first objective of this study was to determine the extent of public drug coverage in each province across Canada for GHRT to treat GHD during adulthood in young adult survivors of PBTs. The second objective was to illustrate out-of-pocket costs incurred by a young adult male and a young adult female survivor of a PBT for one year of GHRT in each province across Canada.

\section{Methods}

\section{Evaluation of provincial drug plans and extent of somatropin coverage}

We initially collected data from provincial government resources and drug formularies from 2012-2013 (Government of Alberta 2012; Government of British Columbia 2013; Manitoba Health 2012; Minister of Health and Wellness 2013; Newfoundland and Labrador Department of Health and Community Services 2013; New Brunswick Department of Health 2012; Nova Scotia Department of Health 2013; Ontario Ministry of Health and Long-term Care 2013; Régie de l'assurance maladie Québec 2013; Saskatchewan Ministry of Health 2012). Subsequently, we determined the extent of coverage and ingredient costs 
for somatropin, the generic name for recombinant human growth hormone administered in GHRT. We contacted provincial ministry of health representatives in order to verify somatropin coverage based on a clinical case scenario. The clinical case scenario consisted of a young adult survivor of a PBT with persistent GHD who was diagnosed with childhood-onset radiation-induced GHD. This patient has achieved final height, is recommended to continue GHRT by an endocrinologist and relies exclusively on public coverage to obtain GHRT.

Afterwards, we collected information that included cost-sharing arrangements inclusive of premiums, deductibles, co-payments and maximum annual contribution by beneficiary, as well as applicable maximum markup on covered prescription medication, maximum professional fees including dispensing fees, and plan restrictions to determine which applicable provincial drug plans met the eligibility criteria for adult survivors of PBTs with GHD (CAPDM 2012; CIHI 2012; Patented Medicine Prices Review Board 2012).

\section{Simulation of out-of-pocket cost for one year of GHRT to treat adult GHD}

After determining the extent of somatropin coverage, the ingredient cost for somatropin and the applicable provincial public drug plan cost-sharing policies, we created a model to simulate out-of-pocket costs incurred in each province to fund approximately one year (360 days) of GHRT for both a young male and a young female adult survivor of a PBT with GHD. Provincial catastrophic drug plans were applied in all provinces where public drug coverage was provided for somatropin to treat GHD in young adult survivors of PBTs. Catastrophic drug plans protect individuals from medication expenses that can result in undue financial hardship by setting limits for the maximum financial contribution an individual must make before the provincial government absorbs costs for all medication expenses (Fraser and Shillington 2005; Health Council of Canada 2005; Phillips 2009). Catastrophic drug plans apply for drugs approved for coverage according to the provincial drug formulary or through evaluation by the provincial government, and drugs not approved for coverage will not contribute towards the individual's maximum financial contribution. This model was based on an extension of work done by Ungar and Witkos (2005), which investigated the general extent of public drug coverage of asthma medication for children across Canada (Ungar and Witkos 2005).

The model consisted of simulating out-of-pocket costs for levels of low annual individual total income, premiums, deductibles, co-payments, maximum markup and maximum professional fees representative of each province. Young adult survivors of PBTs treated with radiation therapy are at high risk for neurocognitive impairment, an outcome that inevitably creates difficulty in securing and maintaining employment (Pang et al. 2008; Reimers et al. 2003). Thus, levels of low annual income were chosen that would represent the majority of young adult survivors of PBTs. Though median incomes for such populations vary slightly across provinces, we used an annual income of CAD $\$ 25,000$ to simulate the upper threshold, and an annual income of $\mathrm{CAD} \$ 15,000$ to simulate the lower threshold. These thresholds were based on the national median individual income of 2010 (Statistics Canada 2010), and 
took into consideration provincial drug plans that offer reduced cost-sharing arrangements for people with low income who do not receive social assistance. The average provincial dispensing fee was taken for provinces from 2012 that did not have regulations on maximum dispensing fees (Telus Health 2012).

A regimen of GHRT was established based on endocrinology consensus guidelines and consisted of non-weight-based recommended dosages of $0.2 \mathrm{mg} /$ day and $0.3 \mathrm{mg} /$ day for young adult men and women, respectively (Ho 2007). To simplify comparisons among the provinces, the medication price established for this regimen was based on the use of Humatrope ${ }^{\otimes} 12$-mg cartridges (Eli Lilly Canada). In the event that provincial drug formularies did not provide the ingredient cost for this formulation of Humatrope ${ }^{\circledast}$, a manufacturer wholesale price of CAD $\$ 560.04$ was used as the ingredient cost, and applicable markup and provincial cost-sharing policies were applied to this price.

The model makes the assumption that the individual does not have private insurance and relies exclusively on public coverage for prescription medications; the individual does not qualify for provincial drug programs designated for individuals on social assistance; and the medication regimen will not require a change in dosage.

Out-of-pocket costs, which included all costs borne by the patient to obtain somatropin, were calculated for each province and were expressed as a percentage of total annual income. Descriptive statistics were used to demonstrate differences in out-of-pocket costs incurred among provinces. The coefficient of variation, which is the standard deviation expressed as a percentage of the mean, was calculated to assess the interprovincial variation for out-of-pocket costs resulting from cost-sharing arrangements in provinces where public drug coverage was provided for somatropin based on our clinical case scenario.

\section{Results}

Somatropin coverage under provincial drug plans for adult GHD in young adult survivors of PBTs

We obtained coverage decisions from all 10 provinces (Tables 1 and 2). Maximum allowable wholesale markup, pharmacy markup and professional fees for each province can be found in Appendix B.

Six provinces - Alberta, Manitoba, Ontario, Quebec, New Brunswick, and Newfoundland and Labrador - provide coverage for GHD during adulthood on a caseby-case basis, while the remaining four provinces - British Columbia, Saskatchewan, Nova Scotia and Prince Edward Island - provide no coverage. Newfoundland and Labrador and New Brunswick provide coverage for somatropin on a case-by-case basis based on satisfaction of specific qualifying criteria under the Select Needs Plan and Plan T - Human Growth 
Hormone, respectively. Individuals qualify on the Select Needs Plan based on a diagnosis of GHD and recommendation of GHRT from an endocrinologist. Plan T - Human Growth Hormone is designated specifically for children under the age of 18 with GHD or hypopituitarism. However, after the age of 18 , a patient can be considered for coverage under special circumstances if that patient was previously receiving coverage during childhood following a review by the expert advisory committee.

Alberta outlines specific criteria (growth hormone values $<3 \mu \mathrm{g} / \mathrm{L}$ during hypoglycaemia based on the results of a diagnostic insulin tolerance test) for coverage of adult GHD, which must be satisfied in order for coverage of somatropin to be granted under special authorization (Government of Alberta 2012).

British Columbia does not provide coverage to treat adult GHD, and coverage remains specific to children 20 years and under, excluding children with Turner's syndrome, PraderWilli syndrome or Noonan's syndrome.

Manitoba, Ontario and Quebec would provide coverage strictly on a case-by-case basis contingent on approval from the expert advisory committee and dependent on the review of all relevant medical information submitted by the patient's endocrinologist.

Saskatchewan does consider coverage for adult GHD under exceptional drug status, but based on the clinical case scenario submitted coverage would not be granted. The provincial drug committee determined that the clinical scenario provided insufficient information for it to make a valid recommendation, and an authentic case would have to be submitted to determine with confidence whether public coverage could be recommended for this indication.

Nova Scotia considers somatropin under exceptional drug status with the satisfaction of preset criteria. Patients with persistent GHD during adulthood in Nova Scotia do not satisfy the preset criteria, which are exclusively for children, and they were not eligible for public coverage after the achievement of final height.

Prince Edward Island has specific criteria for coverage of somatropin, and eligibility is exclusive to children with GHD or Turner's syndrome under the Growth Hormone Program. Coverage would not be granted for adults with GHD.

No provinces explicitly acknowledged in their coverage criteria survivors of PBTs who developed childhood-onset GHD due to radiation therapy with persistent GHD in adulthood.

Provinces differed in the level of subsidy provided for patients, even when somatropin was covered under their prescription drug plan. These variations were attributed to differences in premiums, deductibles and co-payments under provincial drug plans. The only province that provided a full subsidy, and thus resulted in the patient's not bearing any out-of-pocket cost, was Newfoundland and Labrador under the Select Needs Plan. 
TABLE 1. Elements of provincial prescription drug plans providing coverage for GHRT to treat GHD during adulthood for a young adult survivor of a PBT applied in the cost analysis model for $2012-2013$

\begin{tabular}{|c|c|c|c|c|c|}
\hline Programname & $\begin{array}{l}\text { Beneficiary } \\
\text { subgroup }\end{array}$ & Premium & Deductible & Co-payment & $\begin{array}{l}\text { Catastrophic } \\
\text { drug plan }\end{array}$ \\
\hline \multicolumn{6}{|l|}{ Alberta } \\
\hline \multirow[t]{2}{*}{$\begin{array}{l}\text { Non-group } \\
\text { prescription drug } \\
\text { coverage }\end{array}$} & $\begin{array}{l}\text { Net annual } \\
\text { household income } \\
<\$ 20,970\end{array}$ & $\$ 44.45 /$ monthly & None & $\begin{array}{l}30 \% \text { of } \\
\text { prescription charge } \\
\text { to a maximum } \\
\text { of } \$ 25\end{array}$ & \multirow{2}{*}{$\begin{array}{l}\text { Maximum coverage } \\
\text { of } \$ 25,000 \text { and } \\
\text { amount exceeded } \\
\text { will be determined } \\
\text { on a case-by-case } \\
\text { basis }\end{array}$} \\
\hline & $\begin{array}{l}\text { Net annual } \\
\text { household income } \\
>\$ 20,970\end{array}$ & $\$ 63.50 /$ monthly & None & $\begin{array}{l}30 \% \text { of } \\
\text { prescription charge } \\
\text { to a maximum } \\
\text { of } \$ 25\end{array}$ & \\
\hline \multicolumn{6}{|l|}{ Manitoba } \\
\hline \multirow[t]{2}{*}{$\begin{array}{l}\text { Pharmacare } \\
\text { Program }\end{array}$} & $\begin{array}{l}\text { Adjusted family } \\
\text { income } \leq \$ 15,000\end{array}$ & None & $\begin{array}{l}2.73 \% \text { of adjusted } \\
\text { family income }\end{array}$ & None & \multirow{2}{*}{$\begin{array}{l}100 \% \text { of costs will } \\
\text { be covered once } \\
\text { deductible has } \\
\text { been met }\end{array}$} \\
\hline & $\begin{array}{l}\text { Adjusted family } \\
\text { income } \$ 24,00 \text { I- } \\
\$ 25,000\end{array}$ & None & $\begin{array}{l}4.08 \% \text { of adjusted } \\
\text { family income }\end{array}$ & None & \\
\hline \multicolumn{6}{|l|}{ Ontario } \\
\hline \multirow[t]{2}{*}{$\begin{array}{l}\text { Trillium Drug } \\
\text { Program }\end{array}$} & $\begin{array}{l}\text { Net income } \\
\$ 15,000\end{array}$ & None & $\begin{array}{l}\$ 444 \text { year } \\
\text { deductible paid } \\
\text { quarterly }\end{array}$ & None & \multirow{2}{*}{$\begin{array}{l}\text { Once deductible } \\
\text { has been met, } \\
\text { beneficiaries pay } \\
\$ 2 \text { per prescription }\end{array}$} \\
\hline & $\begin{array}{l}\text { Net income } \\
\$ 25,000\end{array}$ & None & $\begin{array}{l}\$ 7 \mid 4 \text { year } \\
\text { deductible paid } \\
\text { quarterly }\end{array}$ & None & \\
\hline \multicolumn{6}{|l|}{ Quebec } \\
\hline Le régime général & $\begin{array}{l}\text { Net income } \\
\$ 15,000-\$ 25,000\end{array}$ & None & \$16.25 per month & $\begin{array}{l}32 \% \text { of the } \\
\text { cost minus the } \\
\text { deductible }\end{array}$ & $\begin{array}{l}\text { Coverage will } \\
\text { be provided } \\
\text { once beneficiary } \\
\text { contributes } \$ 992 \\
\text { per annum or } \\
\$ 82.66 \text { per month }\end{array}$ \\
\hline \multicolumn{6}{|l|}{ New Brunswick } \\
\hline $\begin{array}{l}\text { Plan T - Human } \\
\text { Growth Hormone }\end{array}$ & $N / A$ & $\$ 50$ & None & $\begin{array}{l}20 \% \text { of } \\
\text { prescription charge } \\
\text { to a maximum } \\
\text { of } \$ 20\end{array}$ & $\begin{array}{l}\text { Coverage will } \\
\text { be provided } \\
\text { after beneficiary } \\
\text { contributes } \$ 500 \\
\text { per annum }\end{array}$ \\
\hline \multicolumn{6}{|c|}{ Newfoundland \& Labrador } \\
\hline Select Needs Plan & $N / A$ & None & None & None & $\begin{array}{l}100 \% \text { of costs will } \\
\text { be covered }\end{array}$ \\
\hline
\end{tabular}


Provincial Disparities of Growth Hormone Coverage for Young Adult Survivors of Paediatric Brain Tumours across Canada

Out-of-pocket cost model simulation to treat adult GHD in young adult survivors of PBTs across Canada

Table 2 illustrates the out-of-pocket costs associated with funding 360 days of somatropin to treat adult GHD in both male and female young adult survivors of PBTs for each province after public coverage, if applicable.

TABLE 2. Out-of-pocket costs to fund GHRT for a young adult male and a young adult female survivor of a PBT across Canada for 2012-2013

\begin{tabular}{|c|c|c|c|c|c|c|c|}
\hline Province & $\begin{array}{l}\text { Ingredient } \\
\text { cost }\end{array}$ & $\begin{array}{l}\text { Public } \\
\text { coverage }\end{array}$ & $\begin{array}{l}\text { Annual } \\
\text { income }\end{array}$ & $\begin{array}{l}\text { Total cost } \\
\text { males }\end{array}$ & $\begin{array}{l}\text { Total cost } \\
\text { females }\end{array}$ & $\begin{array}{l}\% \text { of } \\
\text { Annual } \\
\text { income } \\
\text { males }\end{array}$ & $\begin{array}{l}\% \text { of } \\
\text { Annual } \\
\text { income } \\
\text { females }\end{array}$ \\
\hline \multirow{2}{*}{$B C$} & \multirow{2}{*}{$\$ 598.04$} & \multirow{2}{*}{ No } & $\$ 15,000.00$ & \multirow{2}{*}{$\$ 3,588.24$} & \multirow{2}{*}{$\$ 5,382.36$} & 23.9 & 35.9 \\
\hline & & & $\$ 25,000.00$ & & & 14.4 & 21.5 \\
\hline \multirow{2}{*}{$A B$} & \multirow{2}{*}{$\$ 702.04$} & \multirow{2}{*}{ Yes } & $\$ 15,000.00$ & $\$ 416.70$ & $\$ 625.05$ & 2.8 & 4.2 \\
\hline & & & $\$ 25,000.00$ & $\$ 531.00$ & $\$ 796.50$ & 2.1 & 3.2 \\
\hline \multirow{2}{*}{ SK } & \multirow{2}{*}{$\$ 637.89$} & \multirow{2}{*}{ No } & $\$ 15,000.00$ & \multirow{2}{*}{$\$ 3,827.34$} & \multirow{2}{*}{$\$ 5,741.01$} & 25.5 & 38.3 \\
\hline & & & $\$ 25,000.00$ & & & 15.3 & 23.0 \\
\hline \multirow[b]{2}{*}{$M B$} & \multirow[b]{2}{*}{$\$ 571.36$} & \multirow[b]{2}{*}{ Yes } & $\$ 15,000.00$ & $\$ 409.50$ & $\$ 409.50$ & 2.7 & 2.7 \\
\hline & & & $\$ 25,000.00$ & $\$ 1,020.00$ & $\$ 1,020.00$ & 4.1 & 4.1 \\
\hline \multirow{2}{*}{ ON } & \multirow{2}{*}{$\$ 560.04$} & \multirow{2}{*}{ Yes } & $\$ 15,000.00$ & $\$ 230.00$ & $\$ 454.00$ & 1.5 & 3.0 \\
\hline & & & $\$ 25,000.00$ & $\$ 365.00$ & $\$ 724.00$ & 1.5 & 2.9 \\
\hline \multirow[b]{2}{*}{ QC } & \multirow[b]{2}{*}{$\$ 563.07$} & \multirow[b]{2}{*}{ Yes } & $\$ 15,000.00$ & \multirow[b]{2}{*}{$\$ 495.96$} & \multirow[b]{2}{*}{$\$ 743.94$} & 3.3 & 5.0 \\
\hline & & & $\$ 25,000.00$ & & & 2.0 & 3.0 \\
\hline \multirow[b]{2}{*}{ NB } & \multirow[b]{2}{*}{$\$ 583.04$} & \multirow[b]{2}{*}{ Yes } & $\$ 15,000.00$ & \multirow[b]{2}{*}{$\$ 170.00$} & \multirow[b]{2}{*}{$\$ 230.00$} & I.1 & 1.5 \\
\hline & & & $\$ 25,000.00$ & & & 0.7 & 0.9 \\
\hline \multirow[b]{2}{*}{ NS } & \multirow{2}{*}{$\$ 630.94$} & \multirow{2}{*}{ No } & $\$ 15,000.00$ & \multirow{2}{*}{$\$ 3,785.67$} & \multirow{2}{*}{$\$ 5,678.50$} & 25.2 & 37.9 \\
\hline & & & $\$ 25,000.00$ & & & 15.1 & 22.7 \\
\hline \multirow[b]{2}{*}{ PEI } & & & $\$ 15,000.00$ & & & 25.1 & 37.7 \\
\hline & $\$ 628.04$ & No & $\$ 25,000.00$ & $\$ 3,768.24$ & $\$ 5,652.36$ & 15.1 & 22.6 \\
\hline & & & $\$ 15,000.00$ & & & & \\
\hline NL & $\$ 6 \mid 8.54$ & Yes & $\$ 25,000.00$ & $\$ 0.00$ & $\$ 0.00$ & 0.0 & 0.0 \\
\hline
\end{tabular}

Out-of-pocket costs to fund GHRT for a young adult male and a young adult female survivor of a PBT with GHD for 360 days in each province across Canada. Ingredient cost was based on Humatrope ${ }^{\circledR} 12$-mg cartridges and includes maximum markup and professional fees. Levels of low annual income are based on the national median total income of 2010 and prescription drug plan eligibility requirements. Cost is reported for nine and six prescription refills of Humatrope ${ }^{\circledR}$ I2-mg cartridges for females and males, respectively. All costs listed in Canadian dollars. 
There was a higher out-of-pocket cost to treat adult GHD in females compared to males in all provinces that did not provide coverage. This finding was also observed in provinces that provided coverage, except in Manitoba and Newfoundland and Labrador, where coverage was equal. The difference in out-of-pocket costs between females and males was much higher in provinces that did not provide coverage compared to provinces that did provide coverage. Outof-pocket costs were, on average, $1.0 \%$ higher for females than males in provinces that provide unequal coverage, and $10.0 \%$ higher in provinces that did not provide coverage. High variation was observed in provinces that provided public drug coverage for somatropin, a finding that can be attributed to interprovincial differences in cost-sharing policies. The coefficient of variation was $65 \%$ for both males and females at an annual income of $\operatorname{CAD} \$ 15,000$, while the coefficient of variation at an annual income of CAD $\$ 25,000$ was $82 \%$ for males and $66 \%$ for females.

Of the provinces that did not provide coverage, Saskatchewan $(15.3 \%-25.5 \%$ and $23.0 \%-$ $38.3 \%$ for males and females, respectively) incurred the highest out-of-pocket cost based on annual income, while British Columbia (14.4\%-23.9\% and $21.5 \%-35.9 \%$ for males and females, respectively) incurred the lowest. The difference in financial burden of prescription cost between the provinces was not considerable, and variations in cost are due to differences in policies set forth by the provinces on applicable markups and professional fees (Table 2).

Of the provinces that did provide coverage, Manitoba incurred the highest out-of-pocket cost based on annual income for men, and Quebec incurred the highest out-of-pocket cost for women $(2.7 \%-4.1 \%$ and $3.0 \%-5.0 \%$ for men and women, respectively), while Newfoundland and Labrador incurred the lowest ( $0 \%$ for both men and women). These differences in outof-pocket costs among the provinces were due to variations in reimbursement policies of provincial drug plans (Table 2).

\section{Interpretation}

This study illustrates the disparities that exist across Canada in the coverage of somatropin to treat persistent GHD in young adult survivors of PBTs with childhood-onset radiationinduced GHD. This variation is marked by differences in provincial public drug coverage and reimbursement policies. The out-of-pocket costs associated with funding somatropin without coverage are catastrophic, owing to the fact that catastrophic drug plans protect individuals from undue financial hardship only for drugs that are approved for coverage by the provincial government. Females incurred a larger financial burden than males in the majority of provinces. Variation in coverage among public drug plans across Canada put young adult survivors of PBTs with GHD at high risk for cost-related drug non-adherence and undue financial hardship. These findings demonstrate that survivors of PBTs do not have equal access to care and are likely to suffer undue financial hardship in the process of obtaining required medications.

Of particular concern, no province explicitly acknowledged survivors of PBTs in their criteria for coverage. This discrepancy is most likely explained by the low incidence of PBTs and is likely overlooked owing to challenges in creating coverage policies for low-prevalence needs 
(Miltenburg et al. 1996). Provinces may feel that based on administrative practicality, it would be more feasible to address cases on an ad hoc basis rather than develop a specific policy. The discrepancy could also be attributed to the utilitarian approach of provincial budget allocation that, unfortunately, results in the medical needs of vulnerable populations having less priority, in the effort to provide optimal health coverage to as much of the population as possible (Ungar and Witkos 2005). This approach also results in precedent avoidance by the provincial governments, and hence in a way protects governments from the implications of funding expensive treatments in specific populations.

Variation was observed among both out-of-pocket costs and coverage for somatropin among provinces. Remarkably, variations in out-of-pocket costs existed even for provinces that did grant coverage for somatropin. These out-of-pocket costs were expenses that must be borne by patients in order to become eligible for coverage under provincial drug plans. The high variation (coefficient of variation $\geq 60 \%$ ) observed in provinces that provided public drug coverage for somatropin can be attributed to differences in cost-sharing arrangements among public drug plans and have been outlined in previous studies as the cause for inequitable access to medications (Coombes et al. 2004; Daw and Morgan 2012; Demers et al. 2008; Law et al. 2012; Ungar and Witkos 2005). However, approximately $25 \%$ of this variation can be explained by Newfoundland and Labrador, where no out-of-pocket cost was absorbed by the patient to obtain public drug coverage for somatropin. Nonetheless, the variation is still concerning even after removing Newfoundland and Labrador, and indicates that current cost-sharing arrangements contribute to inequitable access to medications. On average each year, young adult survivors of PBTs with GHD would incur CAD $\$ 348.72$ or $\$ 508.03$, at an annual income of $\$ 15,000$ and $\$ 25,000$, respectively, in out-of-pocket costs in provinces that provided public drug coverage for somatropin. These amounts are higher than in Belgium, where adults with GHD are eligible for public drug coverage and incur only between approximately $€ 100$ and $€ 150$ (CAD\$150 to $\$ 227.05$ ) in out-of-pocket costs to obtain public drug coverage for somatropin (Alexopoulou et al. 2010). Out-of-pocket costs were substantially higher in females than males in provinces that did not provide coverage. This finding is due to the higher dose of somatropin that is required for females compared to males to achieve equivalent effects, and hence results in higher cost (Burman et al. 1997; Johannsson et al. 1996).

Studies have shown that healthcare costs, both direct and indirect, are higher in adults with untreated GHD compared to the general population. A significant reduction in healthcare consumption can be observed after initiating GHRT in adults with untreated GHD (Ehrnborg et al. 2000; Hakkaart-van Roijen et al. 1998; Hernberg-Ståhl et al. 2001; Jonsson et al. 2000; Saller et al. 2006; Sanmarti et al. 1999; Svensson et al. 2004). Current Canadian pharmaceutical policy is creating barriers in reducing healthcare consumption/costs for young adult survivors of PBTs, an outcome that is likely to result in increased economic burden on the healthcare system through the increased healthcare consumption required to address the manifestations of GHD. This economic burden is in addition to the multiple healthcare resources required to address the numerous late effects for which survivors of PBTs are at risk (Turner et al. 2009). 


\section{Limitations}

The findings of this study ought to be interpreted in light of its limitations. The model assumes that somatropin is the only prescription medication the patient is taking. This assumption is not representative of most young adult survivors of PBTs who, given their high risk for late effects, will be taking multiple prescription medications (Gleeson and Shalet 2004; Turner et al. 2009). However, the cost of somatropin greatly exceeds the costs of other required medications for young adult survivors of PBTs.

This model assumes that the non-weight-based recommended dosages will be adequate in treating GHD in young adults. In reality, dosage is tailored to the individual and determined by clinical and biochemical response (Ho 2007). Thus, the regimen in the model may not reflect the actual dosage required for every young adult survivor of a PBT with GHD. However, variations from the recommended dosage and actual required dosage are not significant enough to alter conclusions reached by this model.

In addition, there is a possibility that young adult survivors of PBTs may be eligible for coverage of somatropin from health insurance through employment or through a policy in their parents' plans. However, studies have shown that survivors experience significant difficulty in both acquiring and keeping health insurance (Holmes et al. 1986; Hudson et al. 2003). Often private insurance plans have strict criteria, lifetime maximums and expensive premiums that create difficulty in survivors' either obtaining or keeping private insurance.

\section{Conclusions}

Survivors of PBTs are at high risk of medical, neurocognitive and psycho-social late effects. These factors result in an economic burden that inevitably will require support from publicly funded programs to be addressed (Turner et al. 2009). Primary concerns of PBT survivors and their families include losing health insurance, being underinsured and facing the stress of paying for required medical therapies (Turner et al. 2009; "Uninsured" 2000). This study validates the reality of that concern and shows that lack of public coverage puts survivors of PBTs at high risk for cost-related drug non-adherence. This outcome is very likely to result in increased use of healthcare resources and economic burden on society to address the manifestations of GHD, in addition to the healthcare resources required to address their multiple late effects (Law et al. 2012; Turner et al. 2009).

Variations in provincial policies cause undue financial hardship and inequitable access to medications. Policy makers need to adopt a consistent pan-Canadian approach to drug coverage to encompass not only the medical needs of survivors of PBTs, but of all vulnerable populations. This study, like others, supports the need for federal legislation to implement a national drug formulary that has equal cost-sharing arrangements for every Canadian (Coombes et al. 2004; Daw and Morgan 2012; Demers et al. 2008; Romanow 2002; Ungar and Witkos 2005). This recommendation is an achievable strategy to provide equitable access to medications for all Canadians, and has the potential to prevent financial hardship due simply to residence in a particular province. 
Provincial Disparities of Growth Hormone Coverage for Young Adult Survivors of

Paediatric Brain Tumours across Canada

\section{Acknowledgements}

Other authors of this paper include Sabrina Gill, MPH, MD, Adult Endocrinologist, Division of Endocrinology, St. Paul's Hospital and Clinical Associate Professor, University of British Columbia, Vancouver, BC as well as Michelle Johnson, MD, Adult Endocrinologist, Division of Endocrinology, St. Paul's Hospital and Clinical Assistant Professor, University of British Columbia, Vancouver, BC.

This study was supported by the Research and Clinical Trials Advisory Group of the Department of Radiation Oncology, BC Cancer Agency Vancouver Centre and the Brain Tumour Foundation of Canada. This research would also not be possible without support provided by Dr. Mohamed Khan, Professional Practice Leader of the Department of Radiation Oncology, BC Cancer Agency Vancouver Centre. Dr. Fuchsia Howard holds a Michael Smith Foundation for Health Research (MSFHR) Post Doctoral Research Trainee Award.

Correspondence may be directed to: Haroon Hasan, Department of Radiation Oncology, BC Cancer Agency, 600 West 10th Ave., Vancouver, BC V5Z 4E6; tel.: 604-877-6006; e-mail:Haroon.Hasan@bccancer.bc.ca.

\section{References}

Alexopoulou, O., R. Abs and D. Maiter. 2010."Treatment of Adult Growth Hormone Deficiency: Who, Why and How? A Review." Acta Clinica Belgica 65(1): 13-22.

American Cancer Society. 2013. “Brain and Spinal Cord Tumors in Children." Retrieved February 10, 2014. $<$ http://www.cancer.org/cancer/braincnstumorsinchildren/detailedguide/brain-and-spinal-cord-tumors-in-children-survival-rates $>$.

Boston University Radiology. 2008. Pediatric Brain Tumors. Retrieved January 26, 2014. <http://www.bumc. bu.edu/radiology/files/2008/09/pediatric-brain-tumors.pdf>.

Brennan, B., A. Rahim, E. Mackie et al. 1998. "Growth Hormone Status in Adults Treated for Acute Lymphoblastic Leukaemia in Childhood." Clinical Endocrinology 48: 777-83.

Bryant, J., E. Loveman, D. Chase, B. Mihaylova, C. Cave, K. Gerard et al. 2002. "Clinical Effectiveness and CostEffectiveness of Growth Hormone in Adults in Relation to Impact on Quality of Life: A Systematic Review and Economic Evaluation." Health Technology Assessment 6(19): 1-96.

Bunin, G.R., T.S. Surawicz, P.A. Witman, S. Preston-Martin, F. Davis and J.M Bruner. 1998.“The Descriptive Epidemiology of Craniopharyngioma." Journal of Neurosurgery 89(4): 547-51.

Burman, P., A.G. Johansson, A. Siegbahn, B. Vessby and F.A. Karlsson. 1997. "Growth Hormone (GH)-Deficient Men Are More Responsive to GH Replacement Therapy Than Women." Journal of Clinical Endocrinology \& Metabolism 82(2): 550-55.

Canadian Association for Pharmacy Distribution Management (CAPDM). 2012. 2012 Guidebook on Government Prescription Drug Reimbursement Plans and Related Programs. Woodbridge, ON: Author.

Canadian Cancer Society. 2008. Canadian Cancer Statistics 2008. Retrieved February 10, 2014. <http://www. cancer.ca/ /media/cancer.ca/CW/cancer\%20information/cancer\%20101/Canadian\%20cancer\%20statistics/ Canadian-Cancer-Statistics-2008-EN.pdf>.

Canadian Institute for Health Information (CIHI). 2012. "National Prescription Drug Utilization Information System Plan Information Document, July 2012." Retrieved February 10, 2014. < https://secure.cihi.ca/free_products/NPDUIS_PlanInformation_1207_e1.pdf >. 
Carroll, P.V., E.R. Christ, B.A. Bengtsson, L. Carlsson, J.S. Christiansen, D. Clemmons et al. 1998.

"Growth Hormone Deficiency in Adulthood and the Effects of Growth Hormone Replacement: A Review." Journal of Clinical Endocrinology and Metabolism 83(2): 382-95.

Chemaitilly, W. and C.A. Sklar. 2010. "Endocrine Complications in Long-Term Survivors of Childhood Cancers." Endocrine-Related Cancer 17(3): R141-59.

Coombes, M.E., S.G. Morgan, M.L. Barer and N. Pagliccia. 2004."Who's the Fairest of Them All?

Which Provincial Pharmacare Model Would Best Protect Canadians against Catastrophic Drug Costs?"

Longwoods Review 2(3): 13-26.

Darzy, K.H. and S.M. Shalet. 2006. “Pathophysiology of Radiation-Induced Growth Hormone Deficiency:

Efficacy and Safety of GH Replacement." Growth Hormone E IGF Research 16: 30-40.

Daw, J.R. and S.G. Morgan. 2012. "Stitching the Gaps in the Canadian Public Drug Coverage Patchwork?

A Review of Provincial Pharmacare Policy Changes from 2000 to 2010." Health Policy 104(1): 19-26.

Demers, V., M. Melo, C. Jackevicius, J. Cox, D. Kalavrouziotis, S. Rinfret et al. 2008. “Comparison of Provincial Prescription Drug Plans and the Impact on Patients' Annual Drug Expenditures." Canadian Medical Association Journal 178(4): 405-09.

Ehrnborg, C., L. Hakkaart-Van Roijen, B. Jonsson, F.F. Rutten, B.A. Bengtsson and T. Rosén. 2000. “Cost of Illness in Adult Patients with Hypopituitarism." Pharmacoeconomics 17(6): 621-28.

Fraser, K. and R. Shillington. 2005 (April). "Protecting the Unprotected." Canadian Healthcare Manager: 16-17.

Garnett, M.R., S. Puget, J. Grill and C. Sainte-Rose. 2007. “Craniopharyngioma.” Orphanet Journal of Rare Diseases 2: 18. doi: 10.1186/1750-1172-2-18.

Gleeson, H.K., H. Gattamaneni, L. Smethurst, B.M. Brennan and S.M. Shalet. 2004.“Reassessment of Growth Hormone Status Is Required at Final Height in Children Treated with Growth Hormone Replacement After Radiation Therapy." Journal of Clinical Endocrinology \& Metabolism 89(2): 662-66.

Gleeson, H.K. and S.M. Shalet. 2004. "The Impact of Cancer Therapy on the Endocrine System in Survivors of Childhood Brain Tumours." Endocrine-Related Cancer 11(4): 589-602.

Government of Alberta. 2012. Alberta Drug Benefit List. Retrieved February 10, 2014. <https://www.ab.bluecross. $\mathrm{ca} / \mathrm{dbl} / \mathrm{pdf} / \mathrm{dbl} \_$full_list.pdf $>$.

Hakkaart-van Roijen, L., A. Beckers, A. Stevenaert and F.F. Rutten. 1998. “The Burden of Illness of Hypopituitary Adults with Growth Hormone Deficiency." Pharmacoeconomics 14(4): 395-403.

Health Council of Canada. 2005. Pharmaceuticals in Canada: A Background Paper to Accompany "Health Care Renewal in Canada: Accelerating Change." Toronto: Author.

Hernberg-Ståhl, E., A. Luger, R. Abs, B.A. Bengtsson, U. Feldt-Rasmussen, P. Wilton et al. 2001."Healthcare Consumption Decreases in Parallel with Improvements in Quality of Life During GH Replacement in Hypopituitary Adults with GH Deficiency." Journal of Clinical Endocrinology \& Metabolism 86(11): 5277-81.

Ho, K. 2007."GH Deficiency Consensus Workshop Participants. Consensus Guidelines for the Diagnosis and Treatment of Adults with GH Deficiency II: A Statement of the GH Research Society in Association with the European Society for Pediatric Endocrinology, Lawson Wilkins Society, European Society of Endocrinology, Japan Endocrine Society, and Endocrine Society of Australia." European Journal of Endocrinology 157(6): 695-700.

Holmes, G.E., A. Baker, R.S. Hassanein, E.C. Bovee, J.J. Mulvihill, M.H. Myers et al. 1986.“The Availability of Insurance to Long-Time Survivors of Childhood Cancer." Cancer 57(1): 190-93.

Hudson, M.M., A.C. Mertens, Y. Yasui, W. Hobbie, H. Chen, J.G. Gurney et al. 2003. “Health Status of Adult Long-Term Survivors of Childhood Cancer." Journal of the American Medical Association 290(12): 1583-92.

Hulthén, L., B.A. Bengtsson, K.S. Sunnerhagen, L. Hallberg, G. Grimby and G. Johannsson. 2001. “GH Is Needed for the Maturation of Muscle Mass and Strength in Adolescents." Journal of Clinical Endocrinology E Metabolism 86(10): 4765-70.

Johannsson, G., R. Bjarnason, M. Bramnert, L. Carlsson, M. Degerblad, P. Manhem et al. 1996."The Individual Responsiveness to Growth Hormone (GH) Treatment in GH-Deficient Adults Is Dependent on the Level of GH-Binding Protein, Body Mass Index, Age, and Gender." Journal of Clinical Endocrinology E Metabolism 81(4): $1575-81$. 


\section{Provincial Disparities of Growth Hormone Coverage for Young Adult Survivors of Paediatric Brain Tumours across Canada}

Jonsson, B. and B. Nilsson. 2000. “The Impact of Pituitary Adenoma on Morbidity." Pharmacoeconomics 18(1): $73-81$.

Kanev, P.M., J.F. Lefebvre, R.S. Mauseth et al. 1991. "Growth Hormone Deficiency Following Radiation Therapy of Primary Brain Tumors in Children. Journal of Neurosurgery 74(5): 743-48.

Koranyi, J., J. Svensson, G. Götherström, K. Sunnerhagen, B.A. Bengtsson and G. Johannsson. 2001. “Baseline Characteristics and the Effects of Five Years of GH Replacement Therapy in Adults with GH Deficiency of Childhood or Adulthood Onset: A Comparative, Prospective Study." Journal of Clinical Endocrinology E Metabolism 86(10): 4693-99.

Landier, W., S. Bhatia, D.A. Eshelman, K.J. Forte, T. Sweeney, A.L. Hester et al. 2004. “Development of RiskBased Guidelines for Pediatric Cancer Survivors: The Children's Oncology Group Long-Term Follow-up Guidelines from the Children's Oncology Group Late Effects Committee and Nursing Discipline." Journal of Clinical Oncology 22(24): 4979-90.

Law, M.R., L. Cheng, I.A. Dhalla, D. Heard and S.G. Morgan. 2012.“The Effect of Cost on Adherence to Prescription Medications in Canada." Canadian Medical Association Journal 184(3): 297-302.

Littley, M., S.M. Shalet, C.G. Beardwell et al. 1989. “Radiation-Induced Hypopituitarism Is Dose-Dependent.” Clinical Endocrinology 31(3): 363-73.

Madore, O. 2005. The Canada Health Act: Overview and Options. Ottawa: Library of Parliament, Parliamentary Information and Research Service.

Manitoba Health. 2012. Manitoba Pharmacare Program. Retrieved February 10, 2014. <http://www.gov.mb.ca/ health/mdbif/sdr.pdf>.

Miltenburg, D., D.F. Louw and G.R. Sutherland. 1996. “Epidemiology of Childhood Brain Tumors.” Canadian Journal of Neurological Sciences 23(2): 118.

Minister of Health and Wellness. 2013. PEI Pharmacare Formulary. Retrieved February 10, 2014. <http://www. gov.pe.ca/photos/original/hpei_formulary.pdf >.

Ministry of Health Government of British Columbia. 2013. Limited Coverage Drugs - Somatropin. Retrieved February 13, 2014. <http://www.health.gov.bc.ca/pharmacare/sa/criteria/restricted/somatropin.html>.

Molitch, M.E., D.R. Clemmons, S. Malozowski, G.R. Merriam, S.M. Shalet and M.L. Vance. 2006. “Evaluation and Treatment of Adult Growth Hormone Deficiency: An Endocrine Society Clinical Practice Guideline." Journal of Clinical Endocrinology \& Metabolism 91(5): 1621-34.

Mulder, R.L., L. Kremer, H.M. Santen et al. 2009."Prevalence and Risk Factors of Radiation-Induced Growth Hormone Deficiency in Childhood Cancer Survivors: A Systematic Review." Cancer Treatment Reviews 35(7): 616-32.

Newfoundland and Labrador Department of Health and Community Services. 2013. Prescription Drug Program Coverage Status Table. Retrieved February 10, 2014. <http://www.health.gov.nl.ca/health/prescription/coverage_status_table.pdf $>$.

New Brunswick Department of Health. 2012. New Brunswick Prescription Drug Program Formulary. Retrieved February 13, 2014. <http://www.gnb.ca/0212/NBPDPFormulary-e.asp>.

Nilsson, A.G., J. Svensson and G. Johannsson. 2007. "Management of Growth Hormone Deficiency in Adults." Growth Hormone \& IGF Research 17(6): 441-62.

Nova Scotia Department of Health. 2013. Nova Scotia Drug Formulary. Retrieved February 10, 2014. <http:// novascotia.ca/dhw/pharmacare/formulary.asp $>$.

Ontario Ministry of Health and Long-term Care. 2013. Ontario Public Drug Programs Exceptional Access Program. Retrieved February 10, 2014. <http://www.health.gov.on.ca/en/pro/programs/drugs/eap_mn.aspx>.

Pang, J.W., D.L. Friedman, J.A. Whitton, M. Stovall, A.C. Mertens, L.L. Robison and N.S. Weiss. 2008.

"Employment Status among Adult Survivors in the Childhood Cancer Survivor Study." Pediatric Blood \& Cancer 50(1): 104-10.

Patented Medicine Prices Review Board. 2012. Wholesale Up-charge Policies of Canadás Public Drug Plans. Retrieved Apr 4, 2013. <http://www.pmprb-cepmb.gc.ca/english/view.asp?x=1591\&all=true >. 
Phillips, K. 2009. Catastrophic Drug Coverage in Canada. Ottawa: Parliamentary Information and Research Service, Library of Parliament.

Rabinovitch, S.R. 2004. “Evaluation of the Romanow Commission's Recommendation for a National Prescription Drug Formulary." University of Toronto Faculty of Law. Health Law \& Policy Group Student Working Paper.

Régie de l'assurance maladie Québec. 2013. List of Medications. Retrieved February 10, 2014. <https://www.prod. ramq.gouv.qc.ca/DPI/PO/Commun/PDF/Liste_Med/Liste_Med/liste_med_mod1_2013_01_14_en.pdf>.

Reimers, T.S., S. Ehrenfels, E.L. Mortensen, M. Schmiegelow, S. Sønderkær, H. Carstensen et al. 2003. “Cognitive Deficits in Long-Term Survivors of Childhood Brain Tumors: Identification of Predictive Factors." Medical and Pediatric Oncology 40(1): 26-34.

Ries, L.A.G., M.P. Eisner, C.L. Kosary, B.F. Hankey, B.A. Miller and L. Clegg. 2004. SEER Cancer Statistics Review, 1975-2001. Bethesda, MD: National Cancer Institute.

Romanow, R. 2002. Building on Values: The Future of Health Care in Canada - Final Report. Saskatoon, SK: Commission of the Future of Health Care in Canada.

Saller, B., A.F. Mattsson, P.H. Kann, H.P. Koppeschaar, J. Svensson, M. Pompen and M. Koltowska-Häggström. 2006. "Healthcare Utilization, Quality of Life and Patient-Reported Outcomes During Two Years of GH Replacement Therapy in GH-Deficient Adults - Comparison between Sweden, the Netherlands and Germany". European Journal of Endocrinology 154(6): 843-50.

Sanmarti, A., A. Lucas, F. Hawkins, S.M. Webb and A. Ulied. 1999. “Observational Study in Adult Hypopituitary Patients with Untreated Growth Hormone Deficiency (ODA Study). Socio-Economic Impact and Health Status. Collaborative ODA (Observational GH Deficiency in Adults) Group." European Journal of Endocrinology 141(5): 481-89.

Saskatchewan Ministry of Health. 2012. Formulary (61st ed.). Retrieved February 10, 2014. <http://formulary. drugplan.health.gov.sk.ca/Publns/Formularyv62.pdf>.

Shalet, S.M. 1993."Radiation and Pituitary Dysfunction." New England Journal of Medicine 328(2): 131-33.

Sklar, C.A. 1997. "Growth and Neuroendocrine Dysfunction Following Therapy for Childhood Cancer." Pediatric Clinics of North America 44(2): 489-503.

Sklar, C.A. and L.S. Constine. 1995. "Chronic Neuroendocrinological Sequelae of Radiation Therapy." International Journal of Radiation Oncology * Biology * Physics 31(5): 1113-21.

Sklar, C. and S. Wolden. 2011."Therapy for Pediatric Brain Tumors and the Risk of Growth Hormone Deficiency." Journal of Clinical Oncology 29(36): 4743-44.

Stanhope, R. 2004. “Transition from Paediatric to Adult Endocrinology: Hypopituitarism." Growth Hormone E IGF Research 14: 85-88.

Statistics Canada. 2010."Individuals by Total Income Level, by Province and Territory (Canada)." CANSIM Table 111-0008. Retrieved February 10, 2014. <http://www.statcan.gc.ca/tables-tableaux/sum-som/101/cst01/ famil105a-eng.htm>.

Svensson, J., A. Mattsson, T. Rosén, L. Wirén, G. Johannsson, B.A. Bengtsson and M. Koltowska Häggström. 2004."Three Years of Growth Hormone (GH) Replacement Therapy in GH-Deficient Adults: Effects on Quality of Life, Patient-Reported Outcomes and Healthcare Consumption." Growth Hormone E IGF Research 14(3): 207-15.

Telus Health. 2012 (July - December). “Average Dispensing Fee." Retrieved February 10, 2014. <http://ealert.telushealth.com/en/docs/avgdispfee_jul-dec2012.pdf?WT.cg_n=AverageDispensingFee_en >.

Toogood, A.A., W. David, J. Ryder, C.G. Beardwell and S.M. Shalet. 1995. “The Evolution of Radiation-Induced Growth Hormone Deficiency in Adults Is Determined by the Baseline Growth Hormone Status." Clinical Endocrinology 43(1): 97-103.

Turner, C.D., C. Rey-Casserly, C.C. Liptak and C. Chordas. 2009."Late Effects of Therapy for Pediatric Brain Tumor Survivors." Journal of Child Neurology 24(11): 1455-63.

Ungar, W.J. and M. Witkos. 2005. “Public Drug Plan Coverage for Children across Canada: A Portrait of Too Many Colours." Healthcare Policy 1(1): 100.

“Uninsured: Cancer Care Survey Confirms Greatest Concern of Cancer Patients." 2000. Cancer Care News. 